\title{
Industrial network integration development and upgrading model based on industry 4.0
}

\author{
Tang Demiao ${ }^{1,2,3}$ \\ ${ }_{1}^{1}$ Wuhan University of Technology, Hubei, 430070, China \\ ${ }^{2}$ Changshu Institute of Technology, Jiangsu, 215500, China \\ ${ }^{3}$ Fudan University, Shanghai, 200433, China
}

Keywords: Industry network, industry 4.0, service economics.

\begin{abstract}
The new round of industrial revolution featured with industry 4.0 is the important opportunity of industrial development. Under the new normal state, driven from the factors and investment to the intensive development under the driving of innovation, combining with the new trend of new industrial revolution and industry 4.0, focusing on the integration and penetration of internet, boosting the integration of new industry and intelligent internet, the industry will be synergistically developed. The new-typed economic development model centralizing the service economy will be gradually optimized.
\end{abstract}

\section{Proposal of Questions}

With the deep synergy and integration of new industrial revolution and internet, the energy production and use revolution will emerge, as well as great changes in manufacturing model, production organization form and life style and the changes in mass customization and intellectualized production way supported by internet. ${ }^{[1]}$

In the process of the new industrial revolution, new organization variation trend will appear in the industry and among the industries. The mutual integration of internet economy and real economy is deepened gradually. The industrial boundary becomes fuzzy. The manufacturing and service industries will be deeply integrated. The internal organizational structure of the enterprise is flattened and the industrial organization takes on the network form. The way of internet configuration resource is affecting the industrial organizational form. The industrial concentration leads to the network virtual model. [2]

The internet has boosted the consumption upgrading and deeply promoted the industrial transformation. The internet is becoming one of the infrastructures of modern society, which is the important basis of all the commercial thought. The new round of industrial revolution represented by industry 4.0 has boosted the integrated development and smart upgrading of internet and industry. ${ }^{[3]}$

\section{Support Mechanism of Industry 4.0 in Industry Development}

The third industrial revolution successively broke out in the world. It originated from the western countries and was led by them. Our country had no chance to experience all the stages of 3 times' industrial revolution. From 1760 to 1840 , the steam age created by the first industrial revolution made 
the agricultural civilization transited to the industrial civilization. During 110 years from 1840 to 1950 , at the electric age created by the second industrial revolution, the petroleum became the new energy with the heavy industrial rise of electric power, steel, railway, chemical industry and automobile. From 1950 to the third industrial revolution, the changing network technology made the global information and resource exchange become much faster.

Industry 4.0, namely the fourth industrial revolution is one of the 10 future projects confirmed in German "High Technological Strategy 2020", which has become the national strategy. It aims to support the research, development and innovation of new generation revolutionary technology in the industrial field. ${ }^{[4]}$ Germany proposed the industry 4.0 strategy and carried out this strategy in 2013. It aims to improve the competitiveness of German industry and take the first chance in the new round of industrial revolution. The new industrial revolution took on the new features in the many sides of driving mechanism, important industry, division system, influence field and competitive factors. The new industry, new technology, new commercial activities and new business model gradually emerged. The network platform industry represented by new generation information technology, green industry related to the intelligent manufacturing, resource and environment with deep application of new generation information technology, health industry related to the life and food will become the new industry leading the future. ${ }^{[5]}$

Industry 4.0 includes the intelligent factory, industrial network system, IT system, intelligent control of production chain. Under the new technological framework, the enterprise can establish a complete network system via the information system, which includes the mutually linked intelligent machinery, storage system, high-effective product equipment. These equipments can independently run or mutually exchange the information, control each other and synergistically operate via the embedded system.

Industry 4.0 essentially is to transform from the basic model of the central-station control to the basic model of distributed enhancement control in order to establish a production model with the highlyflexible personalized and digitalized product and service. In this kind of model, the traditional industrial boundaries will disappear and various new activity field and cooperative form will be generated. The creation process of new value is changing. The division of industrial chain will be reorganized. This strategy aims to transit the manufacturing industry to intelligence by the full utilization of information and communication technology and network space virtual systeminformation physical system (chart 1 Cyber-Physical System). Regarding the information physical system as the integration of process calculation and physical process, CPS is the next generation intelligent system integrating the computation, communication and control.

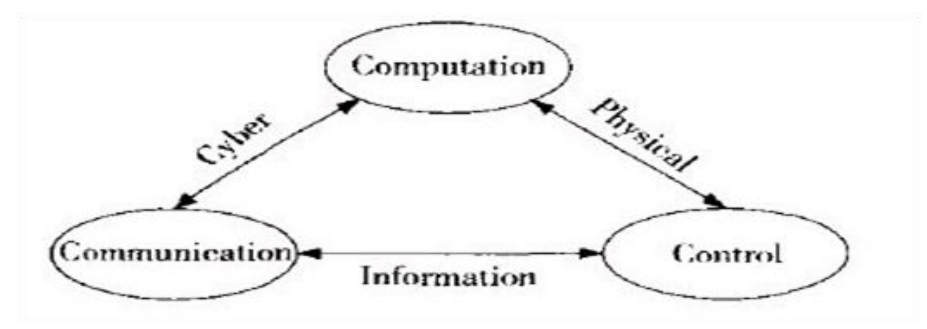

Figure 1. Operating Model of American CPS (Cyber-Physical Systems) Information Physical System

Industry 4.0 intelligent module includes:1: "Intelligent Factory" refers to the intelligent production system and process, realization of networking distributed production facility; 2 "Intelligent Production" mainly refers to the production logistic management of the whole enterprise, manmachine interaction and 3D application in the process of industrial production. 3. "Wisdom Logistic" mainly integrates the logistic resource and fully exerts the efficiency of current logistic resource suppliers via the internet, Things internet and vehicles internet. The demander can quickly obtain the service mating and logistic support. 
For example, practice 4.0 of German Bosch Company includes: intelligent raw material supply, international production network system, monitoring and support system of flow line operation, remote technology support and high-efficiency equipment management system. The enterprise will establish the global network, integrate the machines, storage system and production facilities, mutually operate the wisdom software such as design, production and monitoring by the way of CPS.

\section{New Industrial Development Trend Integrated and Boosted by Industry 4.0}

In the process of development of industry 4.0, the softening trend of industrial structure will emerge. Namely, the gravity of soft industry (service industry) will gradually go up so that the economic servitization emerges. The internal service industry for the third industry is gradually enlarged. Meanwhile, the internal service amount for the first and second industry is gradually expanded. In the process of industrial development, the boosting of high finish degree and technical intensification gradually deepened the dependency on the soft elements such as internet, information technology and knowledge. The industrial development has the character of synergetic intelligence and "service intensity". So, the horizontal and vertical intelligent synergy and integration will appear(figure 2).

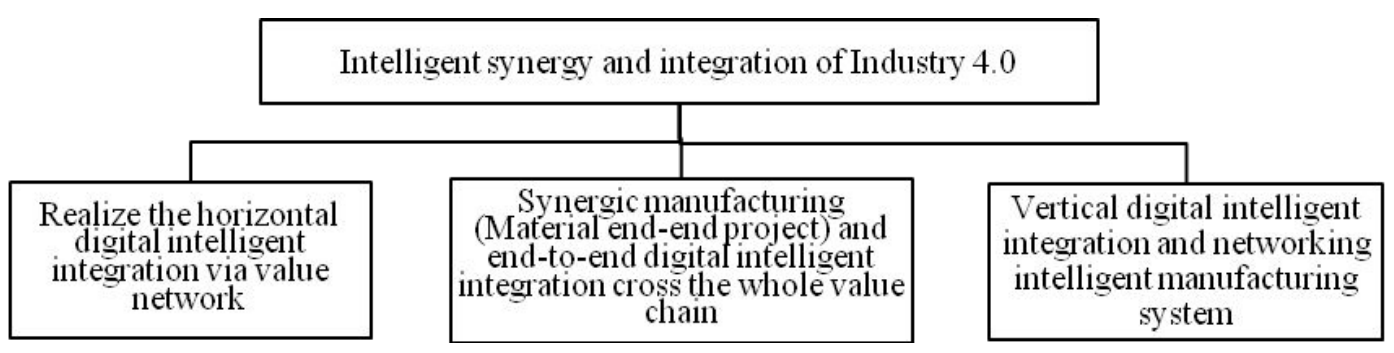

Figure 2. Intelligent synergy and integration model of Industry 4.0

Meanwhile, various technical factors of industry 4.0 have more and more obvious influences on each industrial development. Industry 4.0 technology will be roundly embedded into the industry and service industry. The disruptive innovation of manufacturing technology will break the production flow of traditional products. The manufacturing and service industry is vertically integrated in the industrial chain, the industrial chain is also reorganized. The deep integration of the second and third industry is necessary to be integrated for each process of design, production and sales of products.

The industrial integration can make the independent industrial value chain partially or completely be integrated. The traditional industry can integrate the technology of high technology industry, gradually innovate the new commercial model, realize the vertical cooperation of value chain and horizontal integration among the industries so as to boost the rapid growth of industry. The nodes of new value chain have integrated the value of 2 or more industries. Comparing with the former industry, the integration industry not only has higher additional value and bigger profit space, but also can boost the gradual upgrading and evolution of industrial structure, realize the integration growth among the industries, promote the appreciation of industrial value and upgrade the industrial competitiveness, production industry and economic growth effect. So, the modern industrial system under the framework of industry 4.0 will be formed. ${ }^{[6]}$ 


\section{Industrial Network Integration Development and Upgrading Model under Framework of Industry $\mathbf{4 . 0}$}

Under the framework of industry 4.0, the deep integration of industry and service industry supported by the internet is realized. Namely, regarding "Internet + " as importance, it is for boosting the industrial transformation and upgrading, increasing the development level of producer service and promoting the informatization, servitization and intelligence.

The model for industrial network integration and upgrading is the upgrading of technology, products, function and value chain. It includes 2 basic levels: 1. upgrading in the industry (to high-end industry or high end of industrial chain). The technology and function promotion in the industry is regarded as the advanced extent. 2. Upgrading of industrial structure. The upgrading of value chain is the rationalization among the industries. Utilization of big data can promote the development level of productive service industry including information, research, development, design, logistic and sales, form the integration technology system and service system of new energy and internet and form the driving force, key link and upgrading model (table 1) of industrial integration development under the framework of industry 4.0 .

Table 1. Driving Force-Key Link-Upgrading Model of Industrial Integration Development Under the Framework of Industry 4.0

\begin{tabular}{|c|c|c|}
\hline Driving Force & Key Link & Upgrading Model \\
\hline $\begin{array}{l}\text { Internet and } \\
\text { Renewable } \\
\text { Energy } \\
\text { Technology } \\
\text { Integration } \\
\end{array}$ & $\begin{array}{l}\text { Standard and } \\
\text { Synergic } \\
\text { Framework }\end{array}$ & $\begin{array}{l}\text { Embedded Value Chain Upgrading-Main Chain } \\
\text { Cultivation, The internet is expanded from the } \\
\text { downstream to the upstream in the traditional field. }\end{array}$ \\
\hline $\begin{array}{l}\text { Internet and } \\
\text { Digital } \\
\text { Manufacturing } \\
\text { Technology } \\
\text { Integration }\end{array}$ & $\begin{array}{l}\text { Deconstruction } \\
\text { and Modeling } \\
\text { Management of } \\
\text { Complex System }\end{array}$ & $\begin{array}{l}\text { Transboundary integration of internet and traditional } \\
\text { industry (consumption-industrial internet). Promote } \\
\text { the penetration ability of cloud computing, big data } \\
\text { and E-commerce in the industry, boost the } \\
\text { development of traditional industry to the } \\
\text { intelligence, digitization and networking, especially } \\
\text { use the E-commerce to integrate the upstream and } \\
\text { downstream resource of the whole industrial chain, } \\
\text { speed up the innovation of production flow. }\end{array}$ \\
\hline $\begin{array}{l}\text { Internet } \\
\text { Multiplier } \\
\text { Effect } \\
\text { (Catalyst) }\end{array}$ & $\begin{array}{l}\text { Organizational } \\
\text { Design }\end{array}$ & $\begin{array}{l}\text { Revolute the industrial rules, strengthen the } \\
\text { governmental guidance, set up the platform, combine } \\
\text { the high-grade industrial structure, establish the big } \\
\text { data service, incubate the innovative industry } \\
\text { regarding the intelligent mobility and big data } \\
\text { application as core. Make the breakthrough in the } \\
\text { key technology and products field of countless } \\
\text { transmission, mass data intelligent search, high-end } \\
\text { software and mobile intelligent terminal software. }\end{array}$ \\
\hline $\begin{array}{l}\text { Technical } \\
\text { Process }\end{array}$ & $\begin{array}{l}\text { Comprehensive } \\
\text { Public Network } \\
\text { Facilities }\end{array}$ & $\begin{array}{l}\text { Boost the integration and appreciation of industrial } \\
\text { internet from simple value transmission of the } \\
\text { transaction link to value creation and industrial } \\
\text { integration and appreciation of research, } \\
\text { development, design, production and service link. }\end{array}$ \\
\hline $\begin{array}{l}\text { Independent } \\
\text { Innovation }\end{array}$ & $\begin{array}{l}\text { Operation of } \\
\text { Intelligent } \\
\text { Manufacturing } \\
\text { System }\end{array}$ & $\begin{array}{l}\text { Carry out the industrialized and informationalized } \\
\text { integration and the strategy of "Internet +" }\end{array}$ \\
\hline
\end{tabular}

The choice of industry is the key to realize industry 4.0. It is necessary to greatly develop the new generation information technology industry, Things Internet, E-commerce, advanced materials, 
additive manufacturing technology and biological manufacturing, form the intelligent optimization system regarding the transmission and processing of information, improve the management of network space, develop the intelligent application of industrial intelligence and industrial chain, create the digital innovative platform with generic technology, realize the deep integration of industry at the full life cycle and make the digital platform of intelligent manufacturing.

It is necessary to create the smart power grids regarding the optimization of energy structure, synergic service of network and intelligent development of industry as chances, promote the strategic emerging industry taking the integration development of new energy and internet as the importance. It is necessary to change the traditional industries via the large data, cloud computing, Things Internet, mobile internet, carry out the customized design, production and intelligent operation, apply the new intelligent manufacturing technology to distribute the intelligent manufacturing industry and establish the intelligent and continuous industrial development model.

\section{Conclusions}

The realization of industry 4.0 strategy importantly relies on the development of industries taking the industrial intelligence as technical innovation and application, large data as the important network synergic service so as to form the operable intelligent production system, boost the transmission of production way from the big-scaled extensive production to flexible, intelligent, digital and ecological production, establish the new modern industrial development system regarding industry 4.0 as main elements.

\section{Acknowledgements}

The research work was supported by the National Great Project of Foundation-social science of China. Project of Foundation: Research on the development theory and policy of modern industry system.No.11\&ZD142.

\section{References}

1. Rui Mingjie, The Third Industrial Revolution and Chinese Choice [M], Shanghai, Shanghai Lexicographical Publishing House, 2013: 55-58.

2. Zou Shaoxi, Beijing Industrial Upgrading and Harmonious Development Research [M] Beijing, Economic Management Publishing House, 2014: 146-147.

3. [UK] Victor-Mayer-Schoenberg Kenyon-Cukier Sheng Yangyan, Zhou Tao (Translator) Big Data Age [M] Zhejiang, Zhejiang People's Publishing House, 2013: 16-17

4. [Germany] Urich-Scendr (Chief Editor) Deng Min Li Xianmin (Translator) Industry 4.0-Upcoming Fourth Industrial Revolution [M] Beijing, Mechanical Industry Publishing House 2015: 9-10

5. Wang Zhen, 2014 Yangtze River Delta Area Economic Development Report [M] Shanghai, Shanghai Social Science Publishing House 2014: 2.

6. Zhao Yulin, Leading High-technology Industrial Growth Mechanism [M] Beijing, Science Publishing House, 2012: 268-269. 